\title{
Anak perempuan dan obesitas sebagai faktor risiko kejadian kadar gula darah tinggi pada anak sekolah dasar
}

\author{
Khairina Nur Hidayati, Kartika Pibriyanti*
}

\begin{abstract}
Background : Prevalence of Diabetes Mellitus (DM) in Indonesia is 1.5\%. Diabetes Mellitus is not only suffered by adults, but the age of adolescents and children as well. Risk factors in children include gender, obesity, mealtimes, race, age and genetics. Objective : The objective of the study was to analyze the risk factors of high blood glucose incidence in school children.

Methods : This research was analytic survey with cross sectional approach. The population was all students of SD Negeri 1 Sokoboyo class IV to VI amounted to 82 students. The sample size was 82 students taken by purposive sampling technique. The independent variables include obesity and sex, as well as the dependent variable that is the blood sugar level. Test analysis used is chi-square test with significance level $5 \%(\alpha=0,05)$.

Results : Most of the female sample (54.9\%), 30.5\% were obese and 43.9\% had abnormal blood sugar levels. Girls have a 2,95 times greater risk of having high blood sugar levels than boys. Obese children have 10,25 times greater high blood glucose levels than normal children.

Conclusion : Sex and obesity are associated with blood sugar levels in students class IV s / d VI SD Negeri 1 Sokoboyo Slogohimo District Wonogiri District.
\end{abstract}

Keywords : Sex, obesity, blood sugar level

\begin{abstract}
ABSTRAK
Latar belakang : Prevalensi Diabetes Mellitus (DM) di Indonesia sebesar 1,5\%. DM tidak hanya diderita orang dewasa, namun usia remaja dan anak juga. Faktor risiko DM pada anak diantaranya jenis kelamin, obesitas, waktu makan, ras, usia dan genetik. Tujuan : Tujuan penelitian adalah menganalisis faktor risiko kadar gula darah tinggi pada siswa Sekolah Dasar dari aspek jenis kelamin dan status gizi.

Metode : Jenis penelitian survei analitik dengan pendekatan cross sectional. Populasi adalah seluruh siswa SD Negeri 1 Sokoboyo kelas IV s/d VI berjumlah 82 siswa. Besar sampel sebanyak 82 siswa diambil dengan teknik purposive sampling. Variabel bebas meliputi obesitas dan jenis kelamin, serta variabel terikat yaitu kadar gula darah. Analisis uji yang digunakan adalah uji chi-square dengan tingkat kemaknaan $5 \%(\alpha=0,05)$.

Hasil : Sebagian besar sampel berjenis kelamin perempuan (54,9\%), 30,5\% mengalami obesitas dan 43,9\% memiliki kadar gula darah tidak normal. Anak perempuan mempunyai risiko 2,95 kali lebih besar mempunyai kadar gula darah tinggi dibandingkan anak laki-laki. Anak yang obesitas mempunyai 10,25 kali lebih besar mempunyai kadar gula darah tinggi dibandingkan anak dengan status gizi normal

Simpulan : Anak perempuan dan obesitas merupakan faktor risiko kejadian kadar gula darah tinggi pada anak seolah dasar.
\end{abstract}

Kata kunci: perempuan, obesitas, kadar gula darah, anak sekolah dasar

\section{PENDAHULUAN}

Diabetes melitus (DM) adalah suatu penyakit gangguan metabolisme yang disebabkan oleh kelainan sekresi insulin, ketidakseimbangan antara suplai dan kebutuhan insulin, yang ditandai dengan hiperglikemia. Menurut American Diabetes Asociation, DM dapat diklasifikasikan menjadi beberapa tipe yakni, DM tipe 1, DM tipe 2, DM Gestasional dan DM tipe lain. Beberapa tipe yang ada, DM tipe 2 merupakan salah satu jenis yang paling banyak di temukan (90-95\%). ${ }^{1}$

Indonesia merupakan negara ke empat yang memiliki jumlah penderita DM terbanyak di dunia

Fakultas Kesehatan Masyarakat, Universitas Veteran Bangun Nusantara Sukoharjo. Jl. Letjen Sujono Humardani No 1 Kampus Jombor, Bendosari, Sukoharjo 57521

*Korespondensi : dkartika.02@gmail.com setelah India, Cina dan Amerika Serikat. Di Indonesia diperkirakan jumlah penderita DM akan meningkat signifikan hingga 21,3 juta jiwa pada 2030 mendatang, dimana hanya $40 \%$ yang menyadari mengidap DM. ${ }^{2}$ Provinsi Jawa Tengah merupakan salah satu wilayah di Indonesia dengan prevalensi penderita DM sebesar $1,6 \% .^{3}$ Berdasarkan data yang didapatkan dari Dinas Kesehatan Provinsi Jawa Tengah Tahun 2015 berdasarkan 10 pola penyakit terbanyak pada pasien rawat jalan di rumah sakit tipe B DM merupakan penyakit terbanyak nomor dua setelah hipertensi yakni sebanyak 102.399 kasus. $^{4}$ Menurut data Dinas Kesehatan Kabupaten Wonogiri prevalensi kasus baru DM Tahun 2015 sebesar 28\% dan mengalami kenaikan di Tahun 2016 sebesar 31,9\%. Beberapa pencegahan penyakit DM telah dilakukan oleh pemerintah Kabupaten Wonogiri, namun prevalensi penderita baru DM terus meningkat. ${ }^{5}$ 
Berdasarkan data awal yang didapatkan dari register DM di Puskesmas Slogohimo, pada Tahun 2015 penderita DM sebanyak 237 dan meningkat pada Tahun 2016 menjadi 424. Menjaga agar kadar gula darah tetap normal juga harus dilakukan sejak usia 5 18 tahun karena sekarang ini DM tidak hanya diderita oleh orang dewasa namun juga anak dalam usia remaja dapat menderita DM, dimana usia yang paling rentan yaitu usia 9-12 tahun dengan kondisi anak yang memiliki beberapa faktor risiko yang mempengaruhi kadar gula darah. Faktor - faktor tersebut antara lain yaitu jenis kelamin, obesitas, waktu makan, usia, ras dan genetik. Berdasarkan data register DM tipe 2 di Puskesmas Slogohimo, tahun 2015 dan tahun 2016 jumlah penderita DM tipe 2 masing-masing sebanyak 160 orang dan 215 orang, dengan kendali glikemik buruk sebanyak 117 orang $(42,2 \%)$ dan 111 orang $(34,04 \%)$. Cenderung terjadi peningkatan kasus dari tahun 2015 hingga tahun 2016. ${ }^{5}$

Penyakit DM sebagian besar dapat dijumpai pada perempuan dibandingkan laki - laki. Hal ini disebabkan karena pada perempuan memiliki LDL trigliserida yang lebih tinggi dibandingkan dengan laki - laki, dan terdapat perbedaan dalam melakukan semua aktivitas serta gaya hidup sehari -hari yang sangat mempengaruhi kejadian suatu penyakit. Jumlah lemak pada laki - laki dewasa rata - rata berkisar antara 15$20 \%$ dari berat badan total, dan pada perempuan sekitar 20-25\%. Jadi peningkatan kadar lipid (lemak darah) pada perempuan lebih tinggi dibandingkan pada lakilaki, sehingga faktor risiko terjadinya DM pada perempuan 3-7 kali lebih tinggi dibandingkan pada laki - laki yaitu 2-3 kali. ${ }^{6}$

Data di Kabupaten Wonogiri peringkat pertama kecamatan dengan kasus obesitas tertinggi adalah di Kecamatan Wonogiri setidaknya ada 206 siswa sekolah dasar yang mengalami masalah dengan berat badan. SD Negeri 1 Sokoboyo merupakan sekolah dasar yang berada di wilayah pedesaan dan terlapor di Dinkes memiliki kasus obesitas, SD lain yang terlaporkan adalah sekolah dasar yang berada di wilayah kota dari Kabupaten Wonogiri. Hasil survei pendahuluan yang dilakukan, dari 10 siswa yang dipilih secara acak 3 diantaranya memiliki Z-score $>2$ dengan perhitungan IMT/U, dan dari ketiga anak tersebut memiliki kadar gula darah puasa $>110 \mathrm{mg} / \mathrm{dl}$. Untuk mencegah dan mengendalikan penyakit DM, skrining dapat dilakukan mulai tahap anak usia dini terutama pada anak yang memiliki risiko penyakit DM. Berdasar uraian tersebut, dipandang perlu melakukan penelitian untuk menganalisis faktor risiko kejadian kadar gula darah tinggi pada siswa kelas IV s/d VI di SD Negeri 1
Sokoboyo Kecamatan Slogohimo Kabupaten Wonogiri dari aspek jenis kelamin dan status gizi.

\section{BAHAN DAN METODE}

Jenis penelitian yang digunakan adalah observasional analitik dengan desain penelitian cross sectional. Penelitian ini dilaksanakan di SD Negeri 1 Sokoboyo Kecamatan Slogohimo Kabupaten Wonogiri pada bulan Juni 2017. Populasi adalah seluruh siswa SD Negeri 1 Sokoboyo Kecamatan Slogohimo Kabupaten Wonogiri kelas IV s/d VI yang berjumlah 82 siswa.

Variabel bebas meliputi jenis kelamin dan obesitas, variabel terikat dalam penelitian ini kadar gula darah. Variabel perancu meliputi, umur, ras, genetik dan waktu makan. Variabel perancu dikendalikan dengan kriteria inklusi-ekslusi.

Kriteria inklusi meliputi berusia 9-12 tahun, tidak memiliki riwayat DM dari orang tua dibuktikan dengan pernyataan dari orang tua siswa, puasa 8 jam sebelum penelitian dilaksanakan, dan bersedia menjadi sampel. Kriteria eksklusi adalah siswa yang tidak masuk sekolah pada waktu penelitian berlangsung. Sampel dipilih menggunakan metode purposive sampling dan diperoleh jumlah sampel 82 siswa. Analisis data yang digunakan adalah univariat dan bivariat dengan uji Chi-Square dan koefisien kontingensi.

Tabel 1. Distribusi Frekuensi Karakteristik Subjek Penelitian Berdasarkan Usia, Jenis Kelamin, Status Gizi dan Kadar Gula Darah.

\begin{tabular}{lcc}
\hline Variabel & n & \% \\
\hline Usia (tahun) & & \\
9 & 9 & 10,9 \\
10 & 24 & 29,2 \\
11 & 21 & 25,6 \\
12 & 28 & 34,3 \\
Jenis Kelamin & & \\
$\quad$ Laki-laki & 37 & 45,1 \\
$\quad$ Perempuan & 45 & 54,9 \\
Status Gizi & & \\
$\quad$ Obesitas & 25 & 30,5 \\
$\quad$ Tidak & 57 & 69,5 \\
obesitas & & \\
Kadar Gula & & \\
Darah Puasa & & \\
$\quad$ Normal (75- & 46 & 43,9 \\
110 mg/dL) & 36 & \\
Tinggi (>110 & & \\
mg/dL) & & \\
Jumlah & & \\
\hline
\end{tabular}


Tabel 2. Faktor Risiko Kejadian Kadar Gula Darah Tinggi dari Aspek Jenis Kelamin dan Status Gizi

\begin{tabular}{|c|c|c|c|c|c|c|c|c|}
\hline \multirow{3}{*}{ Variabel } & \multicolumn{4}{|c|}{ Kadar Gula Darah } & \multirow{2}{*}{\multicolumn{2}{|c|}{ Total }} & \multirow{3}{*}{ p-value } & \multirow{3}{*}{$\boldsymbol{R P}$} \\
\hline & \multicolumn{2}{|c|}{ Normal } & \multicolumn{2}{|c|}{ Tinggi } & & & & \\
\hline & $\mathbf{n}$ & $\%$ & $\mathbf{n}$ & $\%$ & $\mathbf{n}$ & $\%$ & & \\
\hline \multicolumn{9}{|l|}{ Jenis kelamin } \\
\hline Laki-laki & 26 & 56,5 & 11 & 30,5 & 37 & 45,1 & 0,019 & 2,95 \\
\hline Perempuan & 20 & 43,5 & 25 & 69,5 & 45 & 54,9 & & \\
\hline \multicolumn{9}{|l|}{ Status Gizi } \\
\hline Obesitas & 5 & 10,9 & 20 & 55,5 & 25 & 30,5 & 0,001 & 10,25 \\
\hline Tidak Obesitas & 41 & 89,1 & 16 & 44,5 & 57 & 69,5 & & \\
\hline
\end{tabular}

\section{HASIL}

Tabel 1 menunjukkan karakteristik subjek penelitian. Usia subjek penelitian berkisar antara 9-12 tahun dan paling banyak berusia 12 tahun yaitu $34,4 \%$. Subjek penelitian dengan jenis kelamin perempuan sebesar 54,9\% dan angka ini lebih tinggi dibandingkan subjek laki-laki $(45,1 \%)$. Terdapat 30,5\% subjek mengalami obesitas dan 43,9\% mempunyai kadar gula darah tinggi.

\section{Jenis Kelamin dan Kejadian Kadar Gula Darah Tinggi}

Tabel 2 menunjukkan bahwa jenis kelamin dan status gizi merupakan faktor risiko kejadian kadar gula darah tinggi pada anak sekolah dasar. Prosentase anak perempuan yang mempunyai kadar gula darah tinggi lebih besar $(69,5 \%)$ dibandingkan anak laki-laki $(30,5 \%)$. Anak perempuan mempunyai risiko 2,95 kali lebih besar mempunyai kadar gula darah tinggi dibandingkan anak laki-laki. Selain itu, prosentase anak obesitas yang mempunyai kadar gula darah tinggi lebih besar $(55,5 \%)$ dibandingkan anak yang tidak obesitas atau normal (44,5\%). Anak obesitas mempunyai risiko 10,25 kali lebih besar mempunyai kadar gula darah tinggi dibandingkan anak dengan status gizi normal.

\section{PEMBAHASAN}

Anak sekolah dasar yang bersedia menjadi subjek penelitian ini berkisar 9-12 tahun. DM tipe 2 relatif terjadi di usia lebih muda pada negara maju, sedangkan negara berkembang terjadi pada kelompok lebih tua. Pada populasi Kaukasia di AS dan Eropa, prevalensi DM tipe 2 meningkat pada usia 17 tahun, namun saat ini sudah terjadi di masa kecil dan remaja. ${ }^{7}$ Berbagai penelitian telah menemukan bahwa perempuan lebih banyak menderita Diabetes Mellitus dibandingkan laki-laki. Hal ini dikaitkan dengan aktifitas fisik, dimana perempuan lebih sedikit aktifitas fisiknya dibandingkan dengan laki-laki. Laki-laki memiliki risiko diabetes yang lebih meningkat cepat dari perempuan. Perbedaan risiko ini dipengaruhi oleh distribusi lemak tubuh. Pada laki-laki, penumpukan lemak terkonsentrasi di sekitar perut sehingga memicu obesitas sentral yang lebih berisiko memicu terjadinya gangguan metabolisme. ${ }^{8}$ Secara umum, massa lemak berhubungan dengan penurunan sensitivitas insulin tubuh, bila terjadi penumpukan lemak berlebih ditubuh maka terjadi intoleransi glukosa. Ini berkaitan dengan jaringan adiposa abdomen yang berlebih kemudian terjadi hiperglikemia hingga DM. ${ }^{9}$

Hasil penelitian ini menemukan bahwa jenis kelamin perempuan yang paling banyak memiliki kadar gula darah puasa tinggi. Anak perempuan berisiko 2,95 kali lebih besar mempunyai kadar gula darah tinggi dibandingkan laki-laki. Hal ini didasari bahwa pada anak laki-laki lebih banyak melakukan aktivitas fisik untuk bermain dalam keseharian, misalnya adalah berlarian ketika jam istirahat sekolah dan ketika bermain dengan teman-temannya sepulang sekolah. Diketahui pada anak perempuan SD 1 Sokoboyo yang terlibat penelitian, mereka cenderung tidak banyak melakukan aktivitas fisik yang berarti. Mereka lebih suka bermain boneka dan pasaran.

Hasil penelitian ini sejalan dengan yang penelitian lain yang menunjukkan terdapat hubungan antara jenis kelamin dengan kadar gula darah puasa pada pengguna layanan laboratorium di RSUD $M$. Djoen Sintang. Namun, Hasil penelitian tersebut menemukan bahwa jenis kelamin laki-laki dengan kadar gula darah puasa lebih banyak dari perempuan yang mengalami kadar gula darah yang tidak normal. Jenis kelamin laki-laki lebih banyak mengalami kadar gula darah puasa tidak normal dibandingkan perempuan hal ini didasari bahwa laki-laki pada saat dilakukan penelitian lebih banyak dari pada perempuan. ${ }^{8}$ Demikian halnya yang di lakukan oleh Syah pada Tahun 2010 yang menemukan bahwa variabel jenis kelamin berpengaruh terhadap kadar gula darah. Hasil tersebut diketahui proporsi jenis kelamin perempuan sebesar $60,1 \% .^{10}$

Perempuan memiliki LDL trigliserida yang lebih tinggi dibandingkan dengan laki - laki, dan terdapat perbedaan dalam melakukan semua aktivitas serta gaya hidup sehari -hari yang sangat mempengaruhi kejadian suatu penyakit. Jumlah lemak 
pada laki - laki dewasa rata - rata berkisar antara 15$20 \%$ dari berat badan total, dan pada perempuan sekitar 20-25\%. Jadi peningkatan kadar lipid (lemak darah) pada perempuan lebih tinggi dibandingkan pada lakilaki, sehingga faktor risiko terjadinya DM pada perempuan 3-7 kali lebih tinggi dibandingkan pada laki - laki yaitu 2-3 kali. ${ }^{6}$

Status gizi juga merupakan faktor risiko tingginya kadar gula darah pada siswa sekolah dasar. Anak yang obesitas mempunyai risiko 10,25 kali lebih besar mempunyai kadar gula darah tinggi. Hasil penelitian ini sejalan dengan penelitian di Denpasar Barat, yang menyatakan terdapat hubungan antara obesitas dengan kadar gula darah puasa pada anak usia 5 - 15 tahun di Kecamatan Denpasar Barat dengan $p$ value $(0,000) .{ }^{11}$ Penelitian lain yang dilakukan juga menyatakan ada hubungan obesitas dengan kadar gula darah, dengan $p$-value 0,045 dan nilai $\mathrm{C}=0,319$ yang menunjukkan hubungan rendah dan berpola positif artinya semakin tinggi nilai indeks massa tubuh (obesitas) maka semakin tinggi kadar gula darahnya. ${ }^{12}$

Obesitas merupakan akibat dari gizi berlebih yang dapat berdampak di usia dewasa yang nantinya berisiko menyebabkan berbagai penyakit degeneratif salah satunya yaitu diabetes melitus apabila tidak melakukan pencegahan dengan merubah pola hidup menjadi lebih sehat. ${ }^{13}$ Kegemukan merupakan faktor predisposisi timbulnya peningkatan kadar gula darah, hal ini dikarenakan pada seseorang yang obesitas terjadi peningkatan kadar trigliserida, pernurunan kadar kolesterol HDL, resistensi insulin, dan peningkatan kadar faktor-faktor inflamasi, sel-sel beta pulau langerhans menjadi kurang peka terhadap rangsangan atau akibat naiknya kadar gula dan kegemukan juga akan menekan jumlah reseptor insulin pada sel-sel seluruh tubuh. ${ }^{14}$

\section{SIMPULAN}

Anak perempuan mempunyai risiko 2,95 kali lebih besar mempunyai kadar gula darah tinggi dibandingkan anak laki-laki. Anak obesitas mempunyai risiko 10,25 kali lebih besar mempunyai kadar gula darah tinggi dibandingkan anak dengan status gizi normal.

Orang tua dan pihak sekolah sebaiknya memperhatikan status gizi dari anak sekolah. Pemeriksaan status gizi secara berkala di sekolah dapat membantu pencegahan terjadinya obesitas dan peningkatan kadar gula darah tinggi pada anak sekolah.

\section{DAFTAR RUJUKAN}

1. ADA (American Diabetes Assosiation). Clinical practice recomendedations report of the expert comite on the diangnosis and clasifications of diabetes melitus diabetes care. USA; 2007.

2. WHO. 2007. Growth reference 5-19 years. [Diakses pada tanggal 10 November 2016]. Available from http://www.who.int/growthref/en/.

3. Kementerian Kesehatan RI. Pedoman Pencegahan dan Penanggulangan Kegemukan dan Obesitas pada Anak Sekolah. Jakarta: Kementerian Kesehatan RI; 2011.

4. Dinkes Jawa Tengah. Profil Kesehatan Provinsi Jawa Tengah 2015. Semarang : Dinas kesehatan Provinsi Jawa Tengah; 2016.

5. Dinkes Kabupaten Wonogiri. Profil Kesehatan Kabupaten Wonogiri Tahun 2016. Wonogiri : Dinas Kesehatan Kabupaten Wonogiri; 2016.

6. Soeharto. Penyakit jantung koroner dan serangan jantung edisi kedua. Jakarta: Gramedia Pustaka Utama; 2008.

7. Steyn,NP dkk. Diet, nutrition and the prevention of type Diabetes. Public Health Nutrition. Feb 2004.;7(1A):147-65

8. Rudi, A; Kwureh, HN. Faktor risiko yang mempengaruhi kadar gula darah puasa pada pengguna layanan laboratorium. Jurnal Stikes Kapuas Raya. 2017; 3(2).

9. Hardman, Adrianne E.; Stensel, David J. Physical activity and health. London : Routledge; 2003.

10. Syah, M. Faktor yang berhubungan dengan penyakit diabetes mellitus tipe 2 di Desa Sekip Kecamatan Lubuk Pakam Kabupaten Deli Serdang tahun 2010. Tidak Dipublikasikan [Skripsi]. Medan: Universitas Sumatera Utara; 2010.

11. Nugroho, Adi. Hubungan antara obesitas dengan kadar gula darah puasa pada anak usia 5-12 di Kecamatan Denpasar Barat. Tidak Dipublikasikan [Skripsi]. Fakultas Kesehatan Masyarakat: Udayana; 2015.

12. Purwandari, H. Hubungan obesitas dengan kadar gula darah pada karyawan di RS Tingkat IV Madiun. Jurnal lp2m Universitas Nusantara PGRI Kediri. 2014; 25(1).

13. Fauziah. Faktor risiko obesitas pada anak. Depok: Universitas Indonesia; 2010.

14. Guyton, A. C., dan Hall, J. E.. Buku ajar fisiologi kedokteran edisi 11. Jakarta : EGC; 2007. 